\title{
Technological advances in Japan's high-rise buildings
}

\author{
Jerzy Szołomicki ${ }^{1}$, Hanna Golasz-Szołomicka ${ }^{2}$

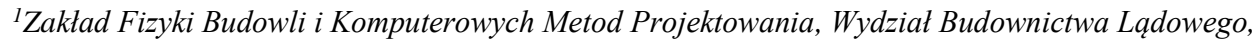 \\ i Wodnego, Politechnika Wrocławska, \\ jerzy.szolomicki@pwr.edu.pl,ORCID0000-0002-1339-4470 \\ ${ }^{2}$ Katedra Historii Architektury, Sztuki i Techniki, Wydziat Architektury, Politechnika Wrockawska, \\ hanna.golasz-szolomicka@pwr.edu.pl,ORCID0000-0002-1125-6162
}

\begin{abstract}
The architectural and structural analysis of selected high-rise buildings in Japan is presented in this paper. Tokyo, Osaka and Nagoya have the largest share in development of high-rise buildings. Those cities are very densely populated and moreover they are located in one of the most active seismic zones. The combination of these factors has resulted in the creation of sophisticated designs and innovative engineering solutions, especially in the field of design and construction of high-rise buildings. The foreign architectural studios (Jean Nouvel, Kohn Pedesen Associates, Skidmore, Owings \& Merrill) which specialize in the designing of skyscrapers, played a major role in the development of technological ideas and architectural forms for such extraordinary engineering structures. Among the projects completed by them, there are examples of high-rise buildings that set precedents for future development. An essential aspect which influences the design of highrise buildings is the necessity to take into consideration their dynamic reaction to earthquakes and counteracting wind vortices. The need to control motions of these buildings, induced by the force coming from earthquakes and wind, led to the development of various methods and devices for dissipating energy during such phenomena. Currently, Japan is a global leader in seismic technologies which safeguard seismic influence on high-rise structures. Due to these achievements the most modern skyscrapers in Japan are able to withstand earthquakes with a magnitude of over seven degrees at the Richter scale. Applied damping devices applied are of a passive type, which do not require additional power supply or active type which need the input of extra energy. In recent years also hybrid dampers were used, with an additional active element to improve the efficiency of passive damping.
\end{abstract}

Keywords: Core structure; damping system; high-rise buildings.

\section{Introduction}

Japan is one of the most densely populated countries in the world, with its capital Tokyo, one of the 47 prefectures, being its largest metropolis. Osaka Prefecture is the third and Aichi Prefecture with capital Nagoya the fourth-most populated. Japan also has one of the most active seismic zones in the world. Geological instability triggers about a thousand earthquakes each year (Fig. 1). The combination of these factors has resulted in the creation of sophisticated designs and innovative engineering solutions, especially of tall buildings. Over 140,000 people died during the Great Kanto earthquake in 1923, which almost completely destroyed Tokyo. The Tohoku earthquake and tsunami of 2011 was the most expensive catastrophe in the world with estimated damage of $\$ 235$ billion. Until the early 1960s Japan's law on construction standards limited the maximum height of buildings. Frequent earthquakes in Japan mean that strictly defined construction standards are needed 
that require skyscrapers to implement security infrastructure, such as quake dampers and special deep foundations. The highest skyscrapers in Japan are mostly office and residential buildings. The urban form of Japan and especially Tokyo is largely a consequence of the reconstruction that occurred after the World War II. In comparison to Europe, where historic brick and stone buildings were built, old buildings in Japan were mostly wooden, and very few of them were reconstructed.

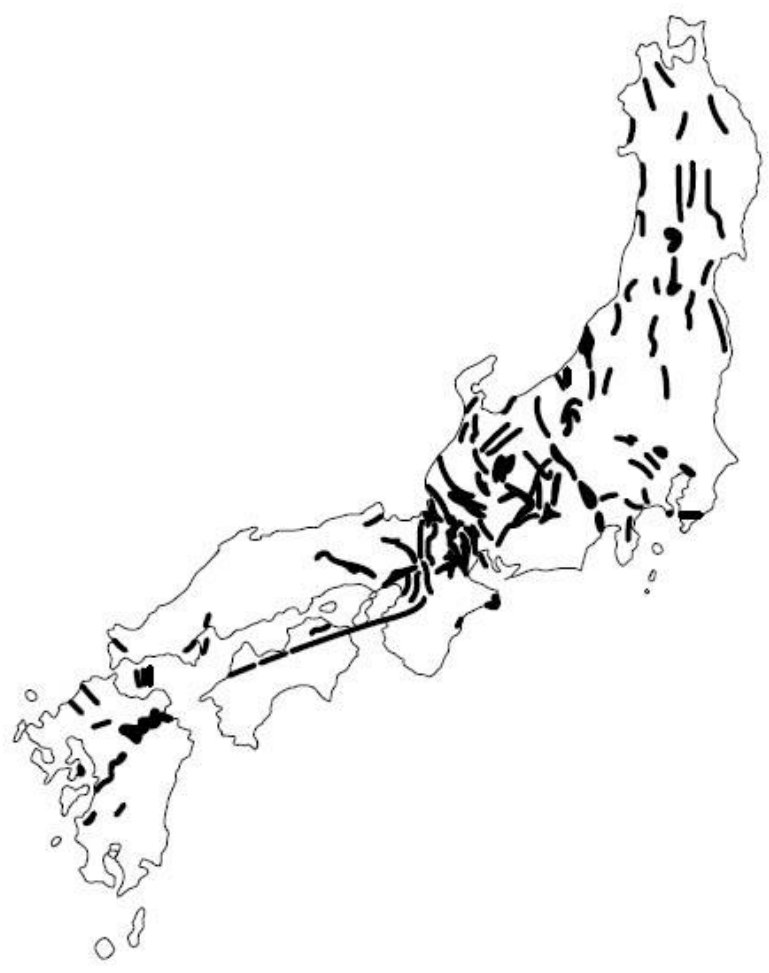

Fig. 1. Map of active faults in Japan (based on website of the Headquaters for Earthquake Research Promotion)

Japan's rapid economic growth continued until the first oil crisis in 1973. It had an influence on the development of urban centers around railway stations and the construction of many lines radiating outward from Tokyo. After the crisis, another stage of urbanization took place from 1970-1990. Tokyo's urbanism can be seen in terms of its architecture, with almost the whole city being completely rebuilt after the World War II. This rebuilding is characterized by the fact that many of its original buildings were designed by architects from around the world. The landscape of Tokyo was largely transformed by technological development. It was a transition from its architecture that in the past appreciated the natural landscape to its present architecture that consumes natural resources and intervenes in the natural landscape. In recent years, the trends to preserve natural resources and ecological solutions have become a priority. The panorama of Japanese cities and in particular Tokyo, Osaka and Nagoya includes many high-rise buildings. Currently in Tokyo there are 149 buildings over $150 \mathrm{~m}$, in Osaka 38 and in Nagoya 11 (Fig. 2). Among these high-rise buildings, 8 were selected for further architectural and structural analysis (Fig. 3). 


\section{Tokyo's skyskrapers 150+}

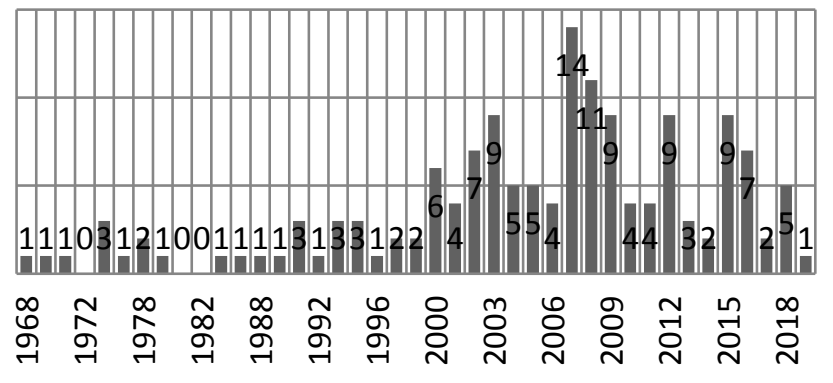

\section{Osaka's skyscrapers $150+$}
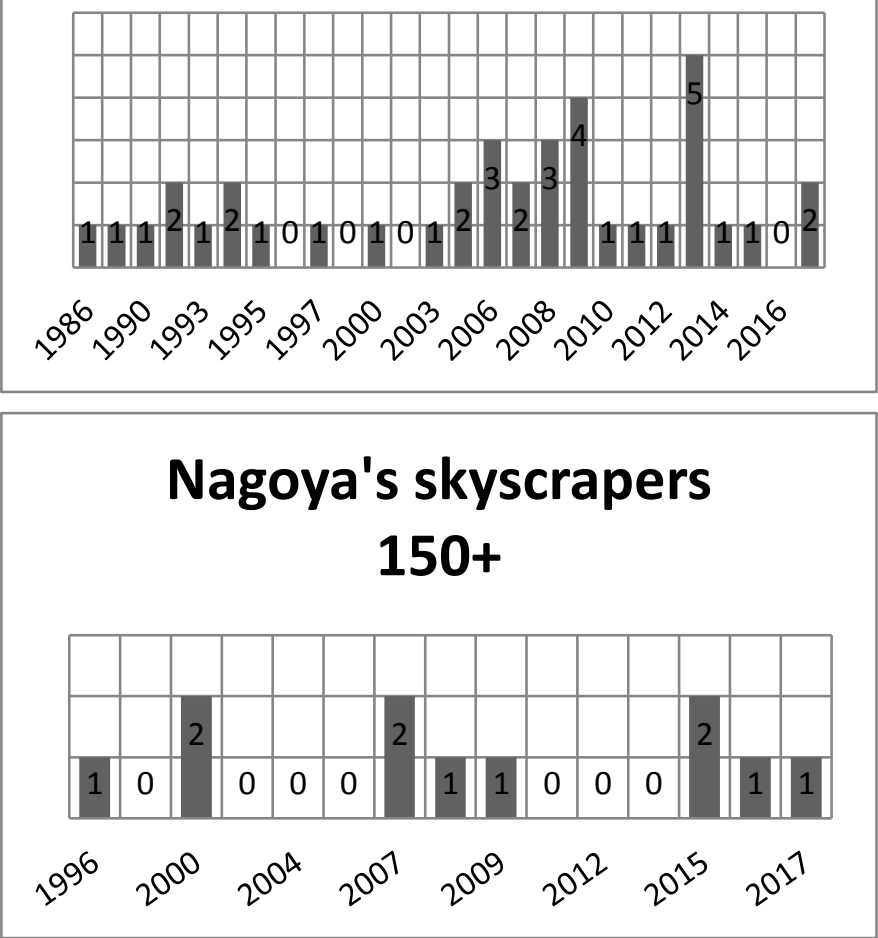

Fig. 2. Building completions timeline (150 m+): Tokyo, Osaka, Nagoya, developed by authors [1] 


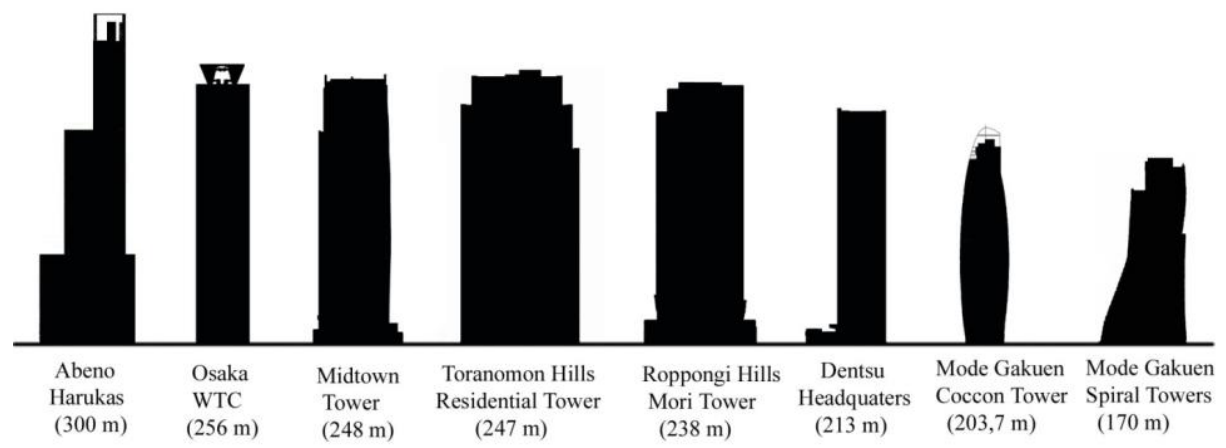

Fig. 3. Selected the tallest high-rise buildings in Japan

\section{The history of tall buildings in Japan}

Japan ranks third in the world after China and US in terms of the number of tall buildings. Tokyo has played a major role in the architectural history of these buildings in Japan $(70 \%$ of all buildings above $150 \mathrm{~m})$. Its architecture has also influenced their construction in Osaka (20\%), Nagoya (5\%) and Yokohama (1\%). The first tall building in Japan was built in 1890 and it was known as Ryonkaku (64 m) [2]. This building located in Asakusa district in Tokyo was damaged as a result of Great Kanto earthquake in 1923. The abolition of buildings height limit to $31 \mathrm{~m}$ in Japanese Law, which was established in 1961, resulted in erection of the Kasumigaseki building in 1968 with $147 \mathrm{~m}$ and 36 floors. It was an opening of the era of skyscrapers in Japan.

In the following years, the height record changed many times. In 1970, the World Trade Center was built in Hamamatsucho with a height of $150 \mathrm{~m}$ and 40 floors, and in 1971 the Keio Plaza hotel was built and had a height of over $200 \mathrm{~m}$. Three years later, the Mitsui building with a height of $220 \mathrm{~m}$ and 55 floors was erected. The highest skyscraper of the first generation was built in 1978 and was the Sunshine building in Ikebukuro. It was the tallest building in Japan until 1992. In 1993, The Yokohama Landmark Tower was built in Yokohama City with a record height of $296,3 \mathrm{~m}$ and 73 floors.

At the beginning of the $21^{\text {st }}$ century, for the first time in history, a significant number of foreign architects with extensive experience in designing of high-rise buildings were invited to cooperate with local architectural studios. Among their projects are examples of tall buildings that set precedents for future development especially in Tokyo . Atago Hill Mori Tower and Forest Mori Tower designed by Cesar Pelli were erected in the Roppongi district in 2001. The corporate center developed by Minoru Mori Roppongi Hills was designed by the New York architectural studio Kohn Pedersen Associates in 2003. In 2007, Tokyo Midtown Tower, designed by Skidmore, Owings and Merrill, was opened.

Since 2014, the tallest building in Japan, Abeno Harukas, has been located in Osaka with a high of $300 \mathrm{~m}$ and 60 floors. An interesting example of high-rise building to solve the problem of the still growing number of inhabitants is the project Next Tokyo 2045. The central building of this project is the $1600 \mathrm{~m}$ Sky Mile Tower, designed by Kohn Pedersen Associates and Leslie E. Robertson Associates, Fig. 4. The skyscraper will be located on a man-made island near the coast of the Tokyo Bay (Fig. 5). The main challenge for the designers was to protect the building against the threat caused by the occurrence of typhoons and earthquakes. The project used a solution in which sea waves that are dangerous to the construction would be broken up by hexagonal objects arranged around the Sky Mile Tower. 

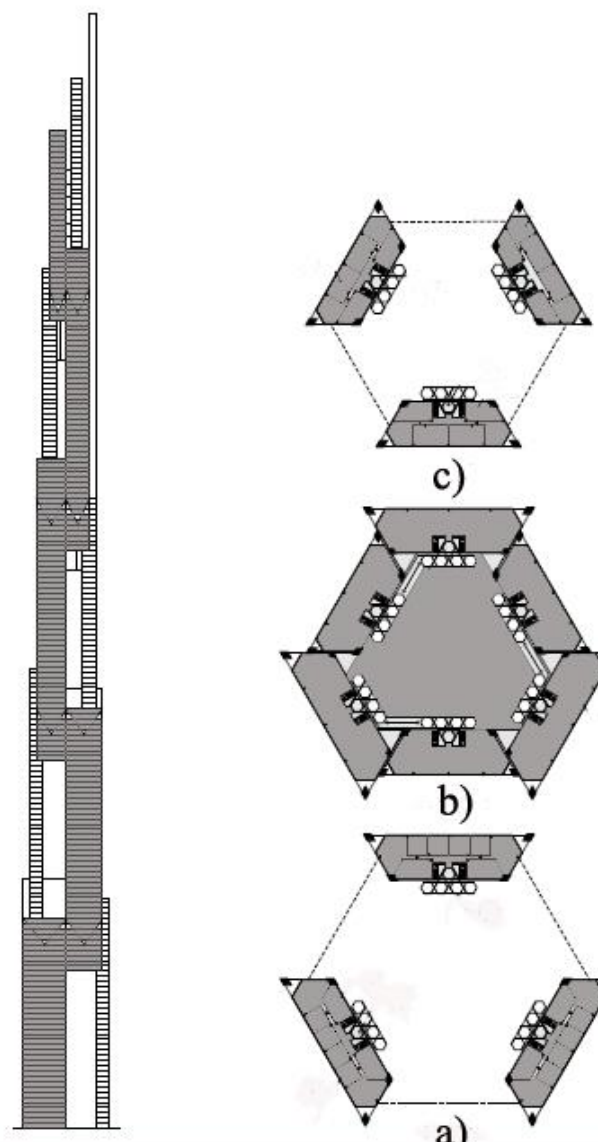

c)
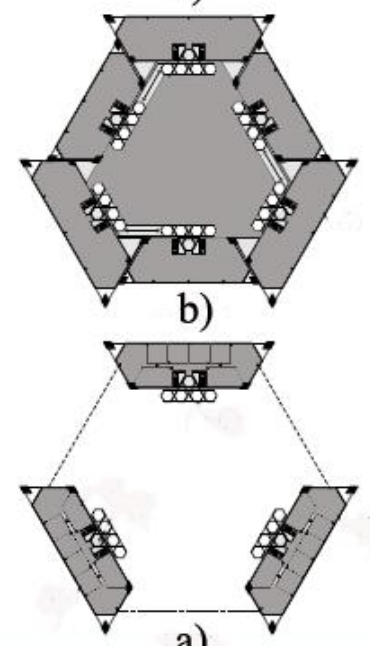

a)

Fig. 4. Sky Mile Tower: floor plans (a) 1-35 floors; b ) 36-40 floors; c) 41-75 floors) and section, developed by authors [3]

Currently, Japan is one of the most advanced countries in terms of development of steel structures. This development is a consequence of evolution between research into steel materials and the standard requirements for building structures. Every year, about 25 million tons of steel is consumed in construction, which is 2.5 times more expensive than in the US [4]. As statistics show, about $30 \%$ of Japanese buildings (in terms of total area) have a steel structure what results in the share of steel structures in Japan being much higher than in other countries.

Despite the unfavorable geographical location associated with the occurrence of frequent earthquakes, Japan can boast of having such building structures as: Akashi Kaiyko bridge (one of the longest suspension bridges in the world, with longest span of $1991 \mathrm{~m}$, 1998), The Tokyo Skytree (the highest free-standing tower, $634 \mathrm{~m}, 2012$ ) and skyscraper Abeno Harukas (the highest skyscraper in Japan, 300 m, 2014).

Undoubtedly, the factor that influenced the creation of these structures was the improvement of the efficiency of steel materials, which favored their development. TMCP technology was used to obtain high-strength steel. This technology is a combination of "controlled rolling", which favors the refining of the microstructure by introducing dislocation in the high temperature range and "accelerated cooling", which realizes the 
quenching effect while suppressing grain growth. With that limited carbon technology highperformance steel materials with excellent weldability and efficiency can be produced.

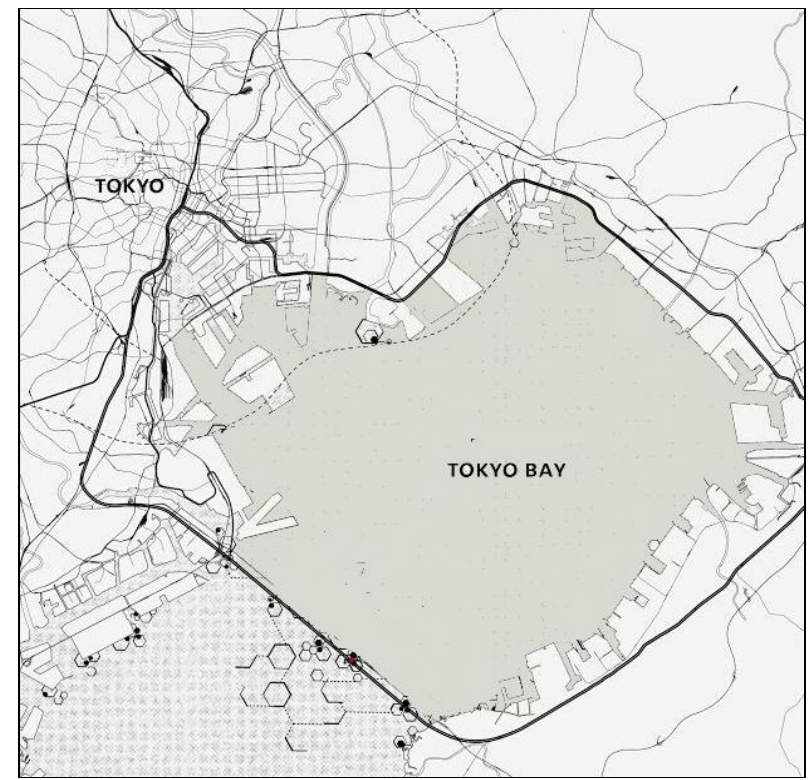

Fig. 5. Site plan of Next Tokyo 2045 [5]

The use of high-strength steel in high-rise buildings was a consequence of their earlier use in bridge constructions. The steel of tensile strength $600 \mathrm{~N} / \mathrm{mm}^{2}$ class was used in Yokohama Land Mark Tower in 1993, and steel of tensile strength $800 \mathrm{~N} / \mathrm{mm}^{2}$ class in Kokura Station in 1998 and Tokyo Skytree in 2012. On the other hand, around 1990, in addition to the tendency to increase the strength of steel, there was a demand for steels with a low yield stress (yield strength $100 \mathrm{~N} / \mathrm{mm}^{2}$ class and yield strength $225 \mathrm{~N} / \mathrm{mm}^{2}$ class), which began to be used for the construction of vibration dampers. Because the plastic deformability of high strength steel is lower than for conventional steels, the performance of entire building is realized by a combined use of dampers.

At present, steel with a tensile strength of over $1200 \mathrm{~N} / \mathrm{mm}^{2}$ is available. This high strength was achieved by the development of a dual-phase steel (DP steel), which has a structure composed of hard and soft material and TRIP steel, in which the plasticity effect of unstable austenite is caused by the martensitic transformation.

\section{Vibration damping systems used in high-rise buildings in Japan}

Buildings in Japan are designed in such a way that they are resistant to seismic activity. An essential aspect of designing tall buildings is their dynamic reaction to earthquakes and counteracting wind vortices. A stiffer building can be achieved with a proper selection of the structural configuration. Tubes, diagrids, and core-supported outrigger structures could be considered more optimal solutions than others. Moreover, high buildings are sensitive to wind-induced vibrations, and the impact of such vibrations becomes dominant for buildings higher than $200 \mathrm{~m}$. Apart from sway movements, wind has a significant impact on the building when the frequency of vortex shedding approaches the 
frequency of its vibration. If the vortices induce vibration of the building equal to its resonant frequency, they can generate a great force and cause a disaster. In this case, designers are creating aerodynamic shapes of buildings or very diverse façades, which prevents the overlapping of vortices. Tall buildings shape modifications were widely described in [6]. Various aerodynamic modifications of the structure of a building can be divided into the following groups:

- a cone-shaped cross-section and a shift back in the building line,

- the façade derived from micro-design features, which interweave structural elements, such as bay windows and balconies into one continuous line,

- a funnel shape and extended spirals upwards and outwards,

- modification of corners.

According to Japanese standards, the following three mean wind speeds are considered when analyzing the wind impact, averaged over 10 minutes with return period of 1 year, 100 years and 500 years. Fulfilling the last case ensures that the building's response is almost completely elastic.

While the strength of building materials, such as steel, has doubled in the last few decades, its stiffness has not increased significantly. This has led to an elastic-based approach to design in which lateral deflections and accelerations are the dominant structural constraints for tall buildings. Vibrations can be partially damped by the structure itself. Increasing the stability of the structure causes an increase in the natural frequency. According to the numerical simulation of the construction response to wind, if the natural frequency is greater, the maximum acceleration decreases approximately in proportion to half of the natural frequency.

The light steel structure used in high-rise buildings has low natural damping or natural dissipation of energy and is sensitive to dangerous accelerations in conditions close to resonance. The dynamic reinforcement of load conditions can be reduced by redistributing stiffness in order to avoid resonance, or by the implementation of a damping system in the building. The need for motion control has led to the development of various methods and devices for dissipating energy. Damping devices can be passive, which do not require additional energy supply, or active, which suppress the reaction with input energy, usually through the use of actuators [7]. Passive systems have fixed properties while active systems change their properties based on the load demand and require an external energy source to be activated. Therefore, while more efficient, active systems are less common due to economic and reliability constraints.

Passive damping systems are divided into three categories: hysteretic dampers, viscous dampers, and mass dampers (Fig. 6).

Hysteretic damping uses steel and steel joint dampers (respectively SD, SJD), as well as viscoelastic dampers (VED), lead dampers (LD) and friction dampers, which are used to reinforce material interactions at the FD connections. Steel vibration absorbers dissipate energy through cyclic inelastic deformation of materials. These damping systems are often designed in the form of a triangular plate or are X-shaped. Due to this shape, plastic deformations appear in a much larger area, which leads to a more efficient dissipation of energy. This system was used in the Ohjiseishi Building in Tokyo (1991), Art Hotels Sapporo in Sapporo (1996), and Kobe Fashion Plaza in Kobe (1997).

In friction dampers, energy dissipation occurs as a result of friction between two solids moving in relation to each other. There are two types of friction dampers used in steel framed buildings: rigid frame friction dampers and braced frame friction dampers. For example, friction dampers were used in the Sonic City Office Tower in Ohmiya (1988) and Asahi Beer Tower in Tokyo (1989). 
Viscous dampers (VD) and oleo-dynamic dampers (OD) use viscous materials in which the resistance force acting on the body moving in the material is proportional to the speed of the body. In this case, high viscosity chemicals such as silicone oil are used. The thermal effect is also significant. VD are particularly effective in the high frequency range and low vibration levels against moderate earthquakes and strong winds. This type of damper, consisting of steel plates is installed as a part of a diagonal brace, where it can dissipate vibrational energy by the shearing action of VE material.

Viscoelastic dampers were used in the TV-Shizuoka Media City buildings in Tokyo (1967) and the Torishima Riverside Hill Tower in Osaka (1999) to counteract the vibrations caused by extremely large earthquakes.

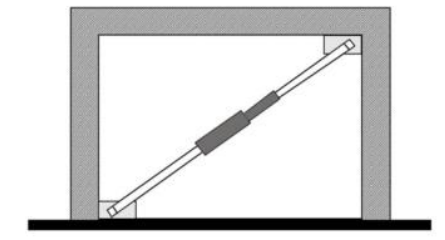

diagonal brace with viscous damper diagonal brace with viscoelastic damper

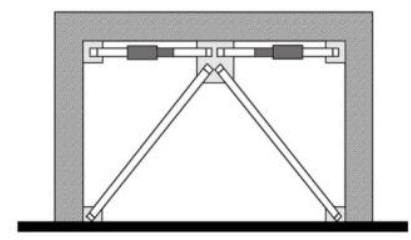

chevron brace with viscous damper

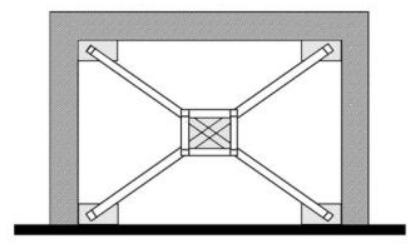

pall friction damper

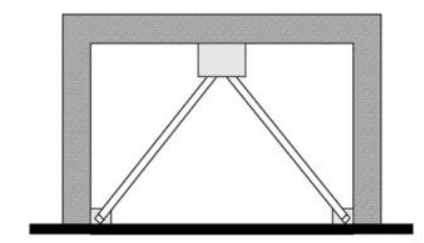

chevron brace with viscoelastic damper

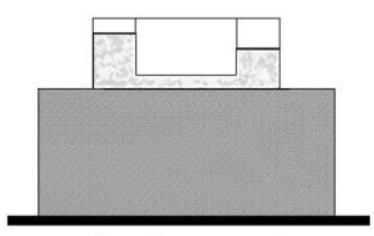

tuned liquid column damper

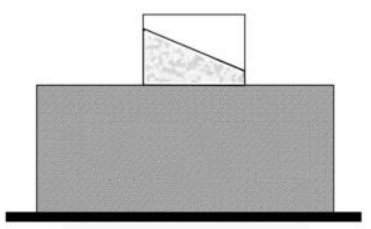

tuned liquid damper

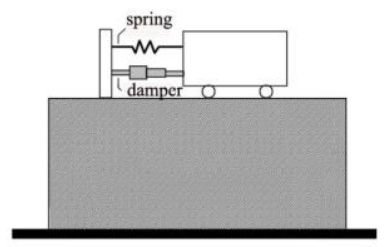

tuned mass damper

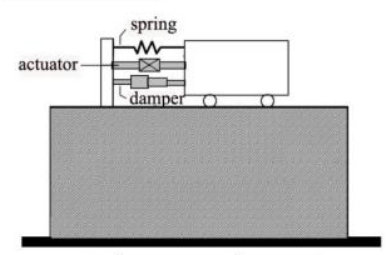

active mass damper

Fig. 6. Vibration damping systems (figure by authors) 
When these devices do not provide sufficient energy dissipation, significant damping can be added to the structure through the use of tuned mass dampers (TMD) [8]. A TMD is an additional mass, usually in the order of $2-5 \%$ of the total weight of the building, which is attached to the structure by means of springs and dashpots. The inertia force of the mass is damping the reaction of the building. However, TMDs are mostly effective only when they are excited by the resonant frequency for which they have been designed. Sometimes, spacing limitations do not permit traditional TMD system, requiring the installation of alternative configurations including pendulums, hydrostatic bearings and laminated rubber bearings. A TMD damper was used in Fukuoka Tower in Fukuoka (1989), Higashimyama Sky Tower in Nagoya (1989) and Huis Ten Bosch Domtoren in Nagasaki (1992).

Another type of mass damping system is tuned liquid dampers (TLD). This damping system uses the movement of liquids in special containers to absorb the energy of building vibrations. TLD vibration frequency can be controlled by the water depth and the size of the container. TLDs are preferred because of their simplicity, low maintenance price and the possibility of including water for emergency fire protection. The TLCD system was used in the Rokko-Island P \& G Building in Kobe (1992), Crystal Tower in Osaka (1992), and Sea Hawk Hotel \& Resort in Fukuoka (1998).

In recent years, hybrid dampers have appeared, which are a combination of a mass damper with an additional active element, which aims to improve the efficiency of passive damping. The forces from the active actuator increase the effectiveness of the mass damper and are very effective in the event of changes in the dynamic characteristics of a structure. The active portion of the system is only used under excitation of a high-rise building, otherwise, it behaves passively. The hybrid system was used in the Landmark Tower building in Yokohama (1993), the Ando Nishikicho building in Tokyo (1993) and in Osaka World Trade Center in Osaka (1994).

\section{Architectural and structural description of selected high-rise buildings}

In this paper the most notable Japan's high-rise buildings located in Tokyo, Osaka and Nagoya were selected for structural and architectural analysis (Fig. 2).

\subsection{Abeno Harukas (Osaka, 2014 )}

Abeno Harukas is a multi-functional skyscraper with a steel structure. This skyscraper is located in Abeno ward on the west side of the Osaka Abenobashi Station [9]. The building is $300 \mathrm{~m}$ high and contains 60 floors above-ground level and 5 floors underground (Fig. 7). It is the tallest building in Japan and the third tallest construction following Tokyo Skytree and Tokyo Tower. The skyscraper design was made by the architectural studio Takenaka Corporation. The superstructure is composed of three blocks having setbacks on the north side. The lower block is for the Kintetsu Department Store with Kintetsu Railway platform on the second floor, the middle one for offices and an Art Museum on the 16th floor and the upper one for a hotel with an observation deck which occupies floors 58-60. The upper block has a large atrium in the center.

The building's planes are $71 \mathrm{~m} \times 80 \mathrm{~m}$ on the basemen and low-rise floors, $71 \mathrm{~m} \times 59 \mathrm{~m}$ on the mid-rise floors and $71 \mathrm{~m} \times 29 \mathrm{~m}$ on the high-rise floors. The foundation of the building is a piled raft foundation which consists of a raft foundation with its bottom depth of $30.5 \mathrm{~m}$ below the ground surface and cast-in-place concrete piles embedded in a very dense gravel layer below a depth of $70 \mathrm{~m}$. 

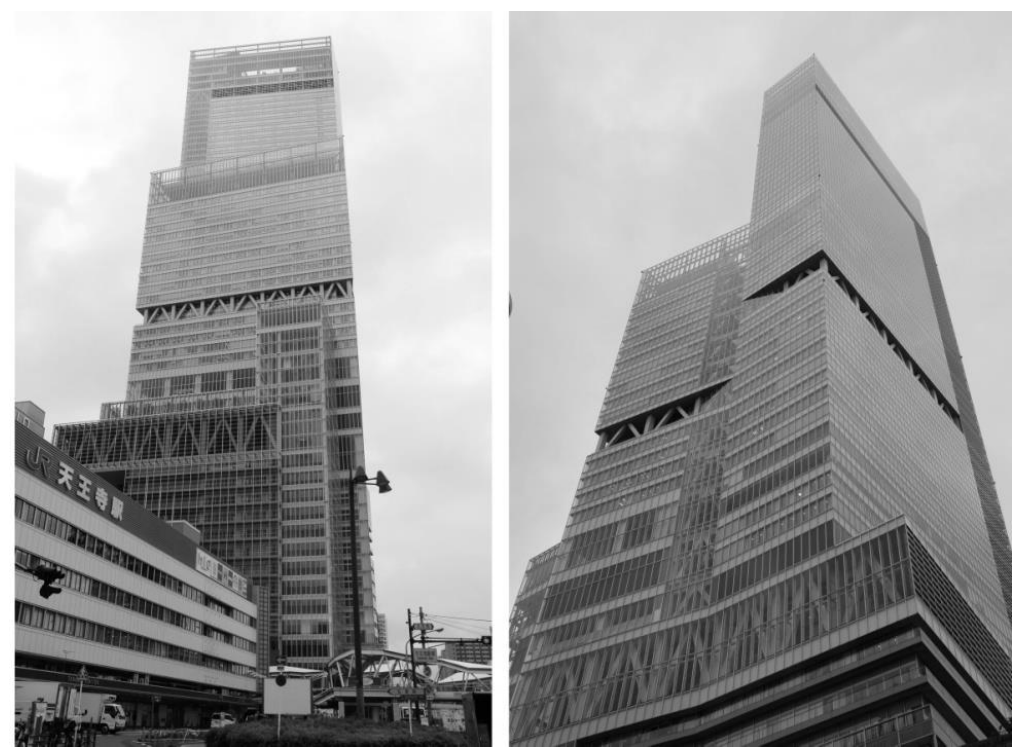

Fig. 7. Abeno Harukas (photographs by authors)
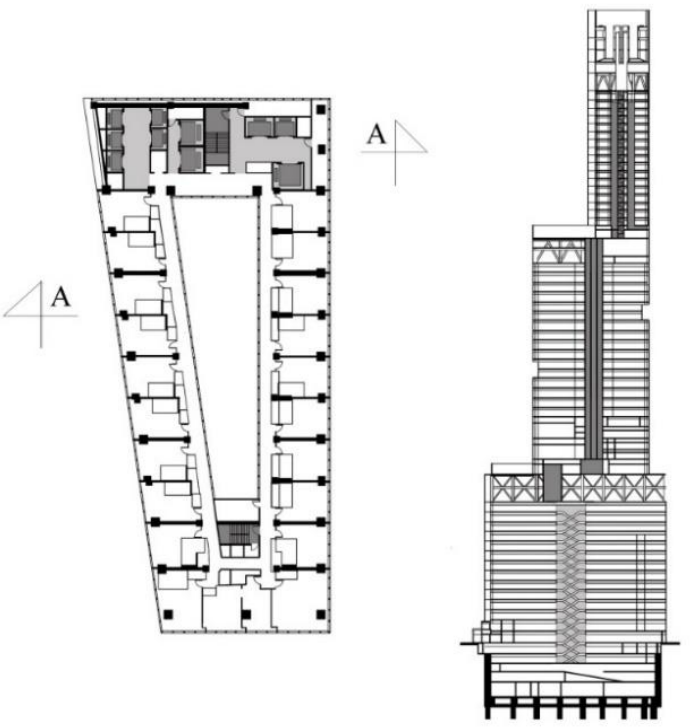

A - A

Fig. 8. Abeno Harukas: floor plan of the 53 and section, developed by authors [9]

Abeno Harukas has an outrigger structure (Fig. 8). This system connects through truss floors to the steel core, using steel plate walls and braces, with the peripheral frame made of steel concrete-filled tubes. Located between the blocks and at the top of the upper one are transfer truss floors. In order to enhance horizontal and torsional rigidity against strong earthquakes and wind excitation, outrigger mega-trusses are placed in the transfer floors and in the middle block. In order to counteract adverse effects there were used four types of 
dampers, both viscous and hysteresistic which were placed at four corners in the lower block around the central core, in the middle block and around the atrium in the upper block. In addition two kinds of mass dampers (active mass damper - MD and active tuned mass damper ATMD) are installed on the $56^{\text {th }}$ floor.

\subsection{Osaka World Trade Center (Osaka, 1995 )}

Osaka World Trade Center is an office high-rise building with steel structures. The WTC Cosmo Tower is located near the bay area of Osaka. It is a part of an extensive new urban center built on artificial island in Osaka Bay known as Sakishima. The WTC is a major landmark in Cosmo Square. The skyscraper design was made by Nikken Sekkei [10].

The building is $256 \mathrm{~m}$ heigh and contains 55 floors above-ground and 3 floors underground (Fig. 9). At the base it widens out in a triangular shape. The low-rise wing includes five storeys high atrium with super-truss structure. The tower houses public space, an auditorium, business support centres and office space ( $7^{\text {th }}$ to $44^{\text {th }}$ floors). The upper floors house a World Trade Center Museum ( $45^{\text {th }}$ floor), sky restaurants, Cosmo Hall, and other functional components. The building is capped by the distinctive inverted pyramid where on the $55^{\text {th }}$ floor at a height 252 is located an observation deck.

The WTC tower is designed on a rectangular plan with a central communication shaft (Fig. 10). The underground part of the building is a steel-encased reinforced concrete structure. A firm 13-m-thick diluvial clay layer covers the entire area below $63 \mathrm{~m}$. The pilings were designed to support the building from this layer. Steel tubes with belied bottom sections and filled with cast-in-place concrete were used. Above ground the tower is constructed of structural steel frames assembled from box-section elements. On the short side of the structure there are two external bracing frames and eight rigid internal frames. From the seventh story downward, a super truss was formed by spreading the external and internal columns outward. The footprint of the building was doubled to stabilize the structure against earthquakes and wind action. In the building have been installed two tuned mass dampers to reduce swaying. A $50 \mathrm{t}$ pendulum was installed in opposite corners of the roof, reducing the response acceleration of the building by approximately $50 \%$.
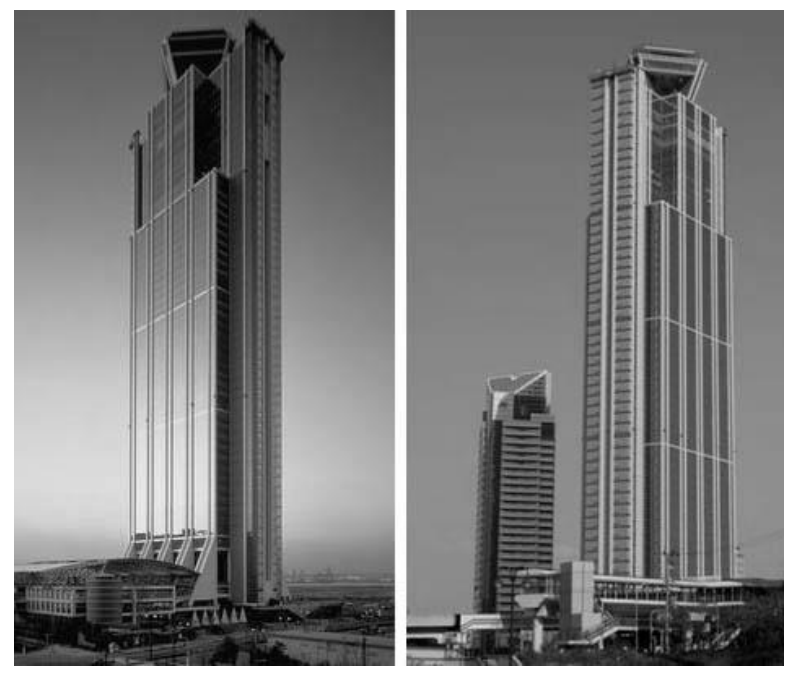

Fig. 9. Osaka World Trade Center (photographs by authors) 


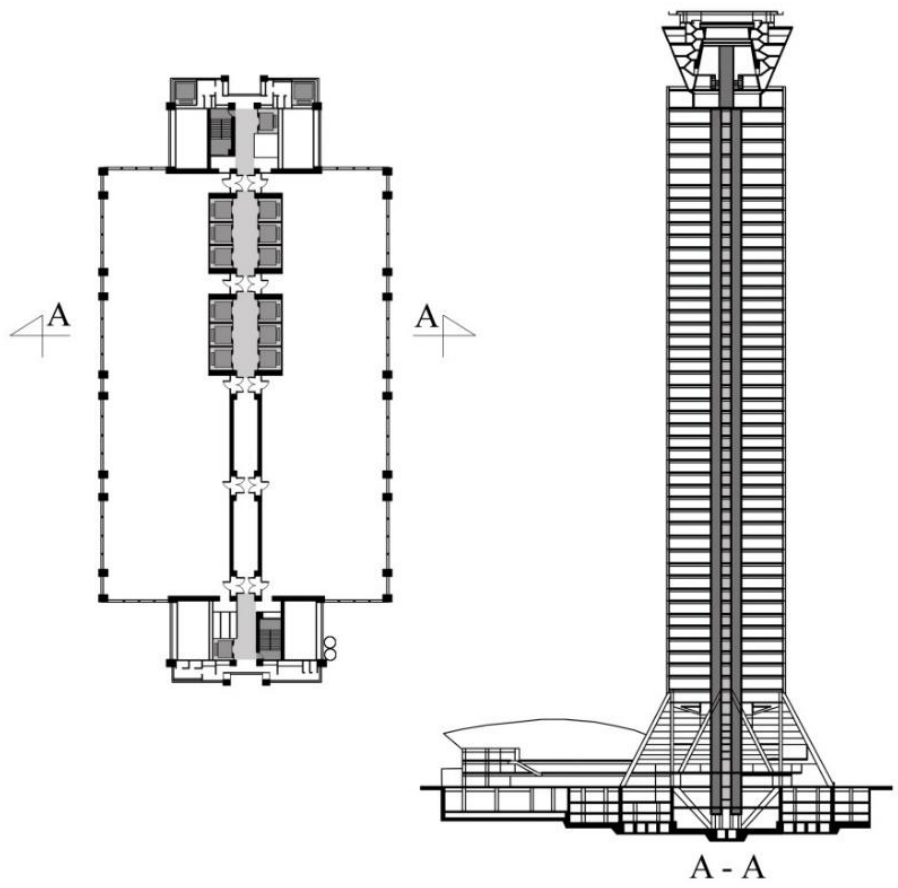

Fig. 10. Osaka World Trade Center: floor plan and section, developed by authors [10]

\subsection{Midtown Tower (Tokyo, 2007)}

Midtown Tower is a multi-functional skyscraper, the tallest of six buildings in the new Tokyo Midtown urban complex [11]. With the transfer of the headquarters of the Japan Defense Agency to the Ichigaya district, a great project to rebuild the area located in the center of Tokyo, containing an extensive range of greenery with the Hinokicho park, has begun. The project of the skyscraper was made by the architectural studios Nikken Sekkei and Skidmore, and Owings \& Merrill.

The building is $248 \mathrm{~m}$ tall and contains 54 floors above-ground level and four underground floors (Fig. 11). The Midtown tower is designed on a rectangular plan with a central communication shaft. In the underground part of the building there is a car park, while above-ground there is a shopping center (floors 1-3, conference center (4th floor), Tokyo Midtown Design Hube gallery and design office (floor 5), Medical Center (6th floor), commercial offices (floors 7-44), and the Ritz-Carlton hotel (floors 45-53)). Unlike similar skyscrapers in the area, such as the Roppongi Hills Mori Tower, the top of the $54^{\text {th }}$ floor of the Midtown Tower does not have an observation deck for visitors. Instead, the floor is occupied by a machine room.

Three buildings in the Midtown Tower complex are located on a massive foundation slab with a length of $230 \mathrm{~m}$ on each side. The main load-bearing structure of the tower consists of steel frames, steel columns filled with concrete and an internal frame core (Fig. 12). Midtown tower sits on rubber pads. This is a system known as base isolation, where the building is separated from the ground by a layer of rubber or ball-bearings. In order to counteract seismic impacts, buckling stabilizers and viscous oil dampers were used. 

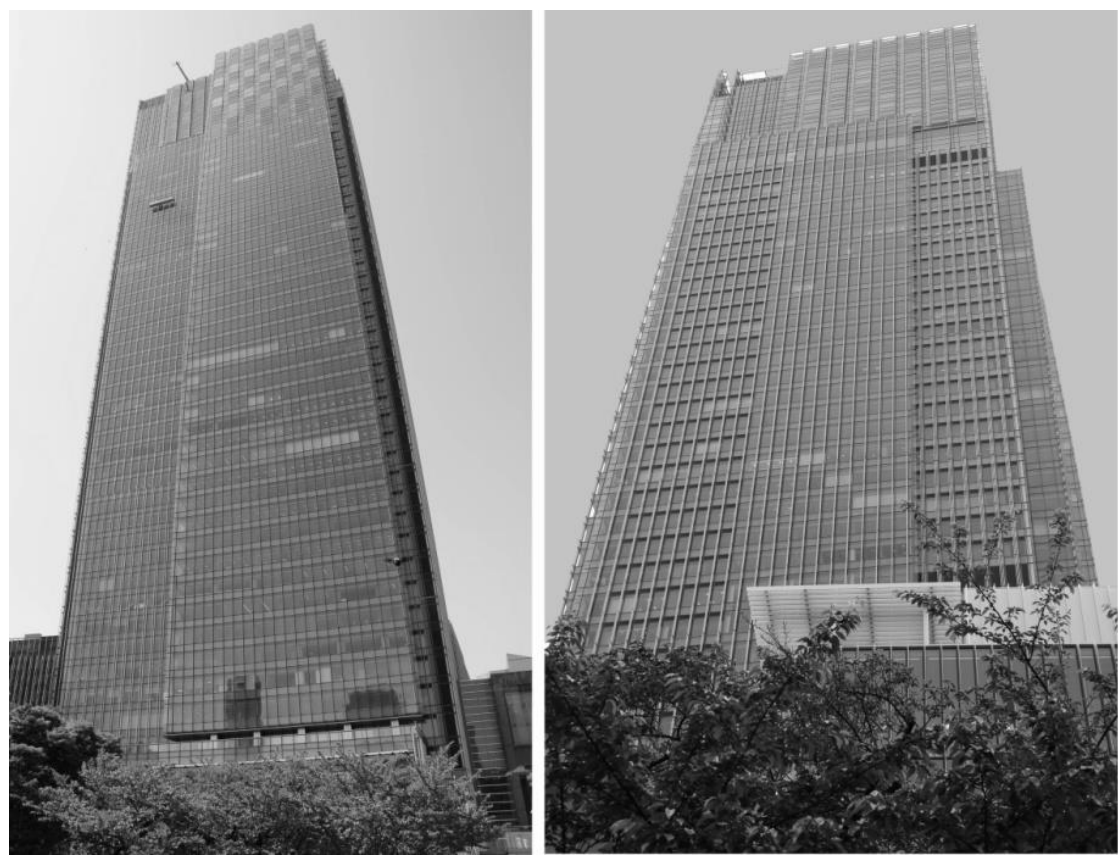

Fig. 11. Midtown Tower (photographs by authors)

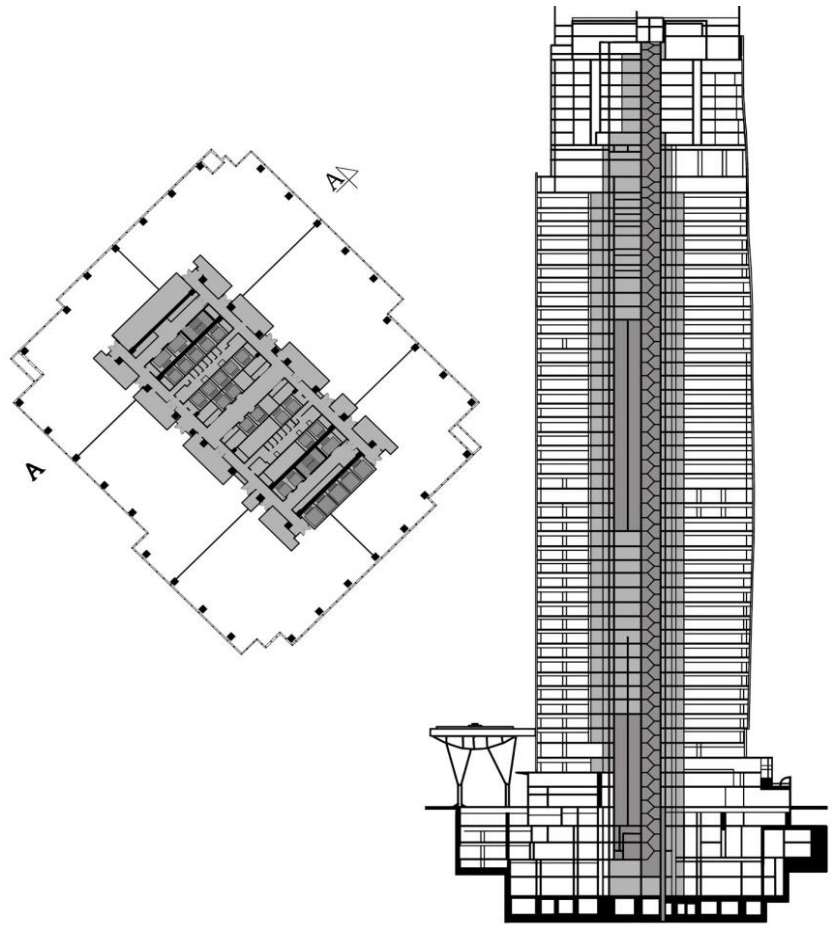

section A-A

Fig. 12. Midtown Tower: floor plan and section, developed by authors [11] 


\subsection{Toranomon Hills (Tokyo, 2014 )}

Toranomon Hills Mori Tower is a multi-functional skyscraper with a steel and reinforced concrete structure designed in the Toranomon Hills complex, the creator of which, as with Roppongi Hills, was Minoru Mori.

The building is $247 \mathrm{~m}$ high and contains 52 floors above-ground level and 5 underground floors (Fig. 13). The building was designed, by the architectural studio Nikhen Sekkei, on an elongated hexagon plan with two rounded opposite corners and with a central communication shaft on a rectangular plan. In the underground part there is a car park, on floors 1-3 commercial buildings, floors 4-5 occupy a conference center, floors 6-35 are intended for offices, floor 36 includes a spatial truss structure, floors 37 to 46 occupy the living spaces, and the hotel Andaz occupies the above floors. The skyscraper was designed around the new communication Loop Road 2 connecting Toranomon and Shimbashi as part of the loop around Tokyo. The Loop Road 2 that runs underground connects the eastern side of the building (Fig. 14) with a tunnel at the second underground level [12]. The road runs through a tunnel structure, which was built independently of the building's structure. In order to avoid the impact of road traffic vibrations on the building, the building's structure is isolated from the running structure by the introduction of material damping vibrations. Noise is reduced with the use of a Sylomer mat (polyurethane elastomer).
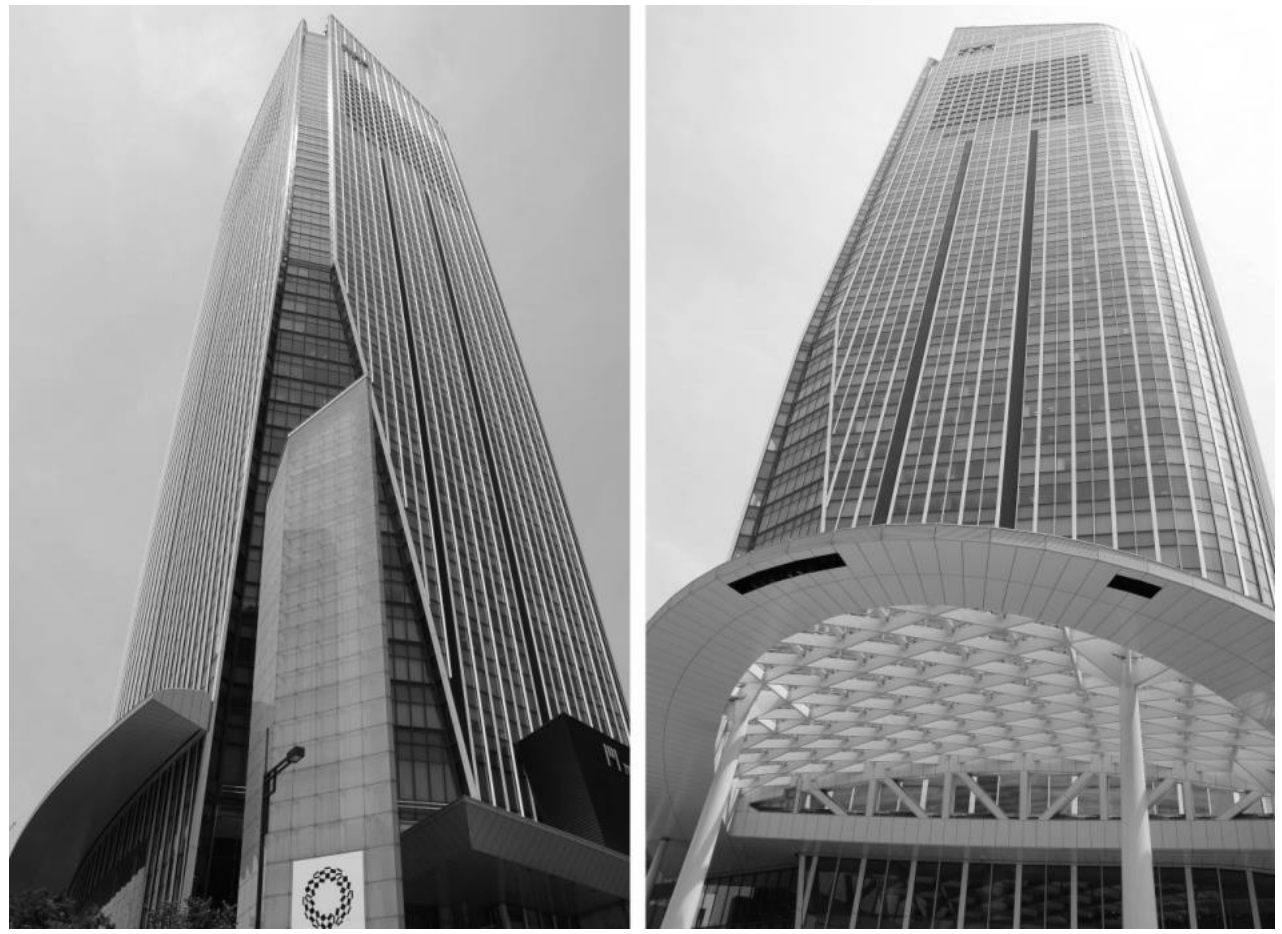

Fig. 13. Toranomon Hills (photographs by authors) 


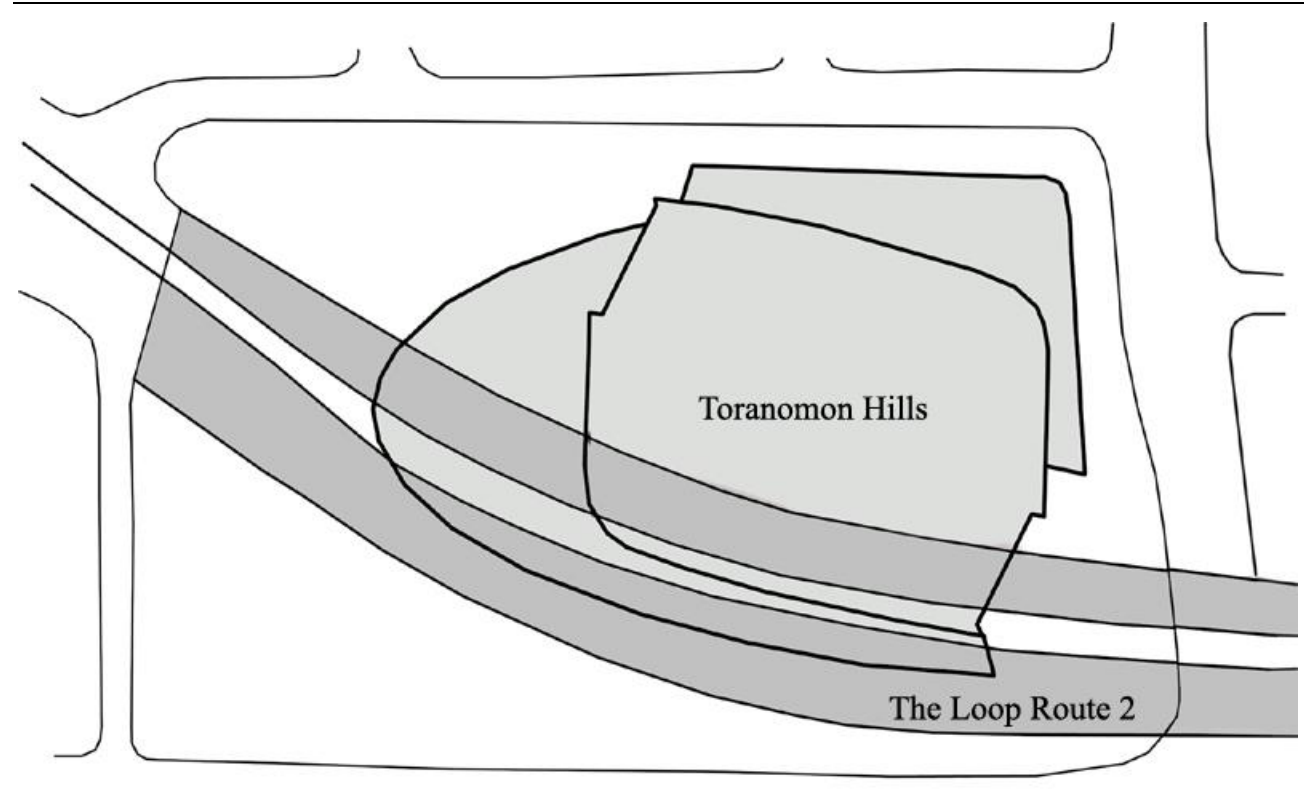

Fig 14. Toranomon Hills: Site Plan, developed by authors [12]

The skyscraper has a raft foundation that cooperates with reinforced concrete piles. The spread foundation of Toranomon Hills is built directly into solid ground called Tokyo Layer. The main load-bearing structure of the above-ground part of the building is a steel frame structure with steel columns filled with concrete and a central reinforced concrete core (Fig. 15). The underground part has a mixed construction consisting of steel and reinforced concrete frames. The podium construction on the Loop Road tunnel consists of prefabricated reinforced concrete slabs with a thickness of $1 \mathrm{~m}$. In the corners of the part of the building that has sharp angles, which are located in the north-west, south-east and south directions on floors 8 to 13, there is a system of inclined two columns, which intersect and pass into one column on the floors below. In the locations of this passage, there is a steel connection with a weight of 20 tons, which allows the load to be transferred from two columns to one. Due to the change of the structural layout in the sector above the $35^{\text {th }}$ floor and the introduction of columns at a distance of $9 \mathrm{~m}$ from the outer edge of the building, on the $36^{\text {th }}$ floor, a spatial truss with a height of $1 \mathrm{~m}$ was used (Figure 16). The crowning of the skyscraper is a steel structure inclined towards the east-west in the shape of shifted pyramids. In order to transfer forces from the roof to the building, two Keel trusses were used. The longest diagonal roof element has a length of $30 \mathrm{~m}$ and is covered with reinforced concrete slabs in order to increase its stiffness in the plane.

The use of a steel mega frame in the construction of the skyscraper effectively counteracts deformations coming from the bending of the entire building. Additionally, viscous oil dampers, buckling stabilizers in the form of diagonal braces and friction dampers as devices controlling shock and vibration reactions were used. 

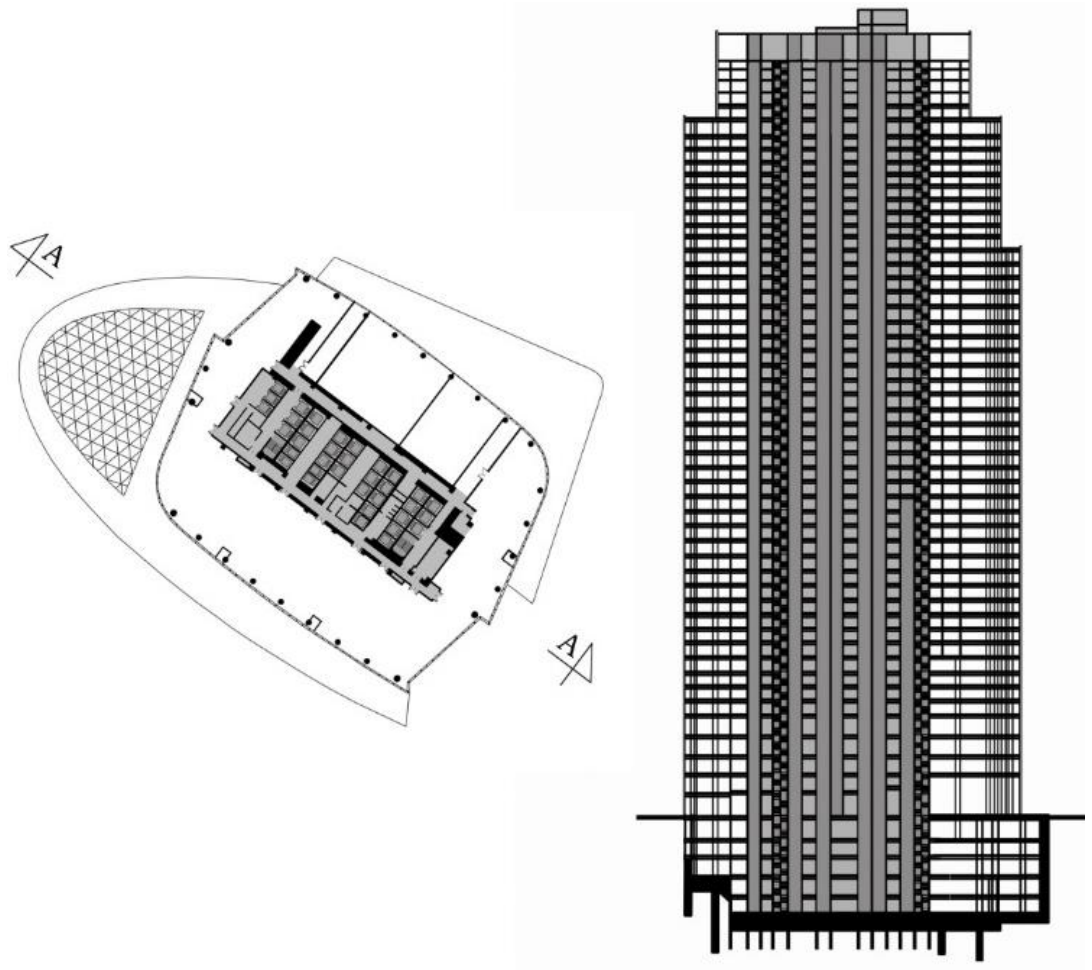

section A-A

Fig. 15. Toranomon Hills: floor plan and section, developed by authors [12]

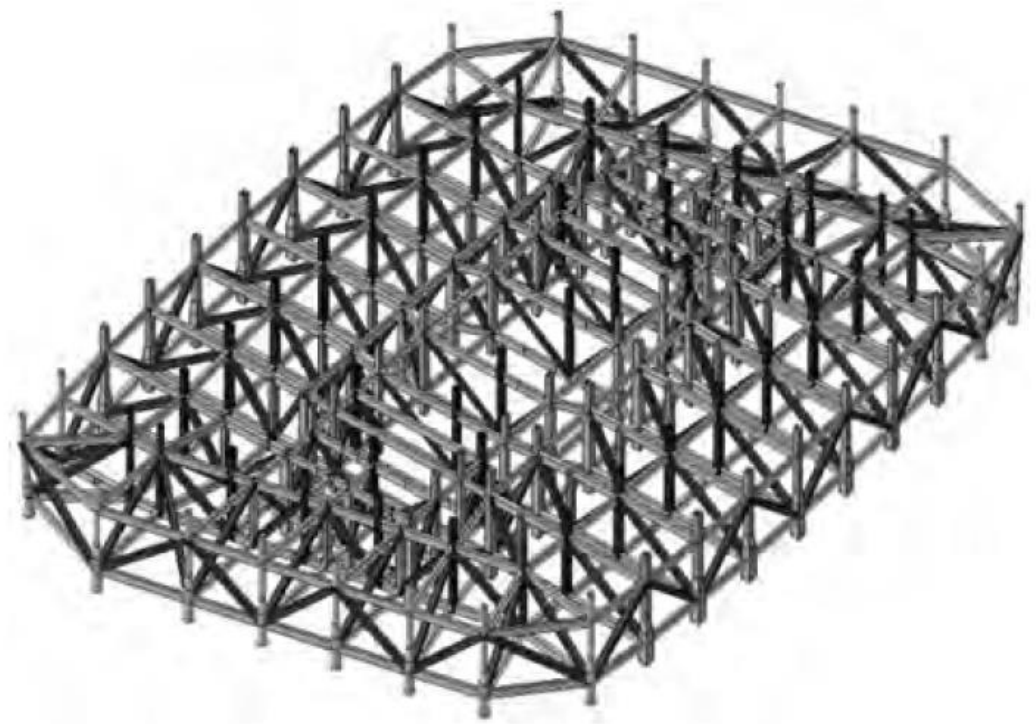

Fig. 16. Toranomon Hills: Structural spatial truss on the 36th floor [12] 


\subsection{Roppongi Hills Mori Tower (Tokyo, 2003)}

Roppongi Hills Mori Tower is a multi-functional skyscraper with a steel and reinforced concrete structure. The structure is the central point in the mega-complex that comprises office buildings, apartments, the Grand Hyatt hotel, the Asahi television studio and an amphitheater. The creator of this complex was the potentate of the building market Minoru Mori, who realized his vision of a global city. It is one of the largest urban complexes in Japan, which has been transformed from small building plots and surrounded by lush greenery that is combined with various urban functions.

Roppongi Hills is $238 \mathrm{~m}$ high and contains 54 floors above-ground level and six underground floors (Fig. 17). The building was designed by a team led by Eugen Kohn, William Pedersen and Paul Katz from the architectural studio Kohn Pedersen Fox Architects. The usable area of the skyscraper, when compared to this type of facility, is one of the largest in the world. The building is designed on a concave-convex octagon plan with a central communication shaft on a square plan. On the first six floors, there are shopping facilities and restaurants, floors 7-48 serve as offices of various corporations, and the Mori Art Center is located on floors 49-54. The central element of this center is the Mori Art Museum located on the $53^{\text {rd }}$ floor, which was designed by Gluckman Mayner Architects. The observation terraces were designed on floors 52 and 54. The form of the building was implemented in accordance with traditional Japanese architecture. In the facades, horizontal and diagonal lines have maximized the amount of glass and steel, just like in the folds of a paper origami sculpture.

The skyscraper has a raft foundation that cooperates with reinforced concrete piles. The main load-bearing structure of the building consists of steel frames, steel columns filled with concrete and an internal frame core (Fig. 18). In order to counteract seismic actions, were installed 192 hydraulic oil dampers and braces made of flexible steel with a low yield strength [13], [14].

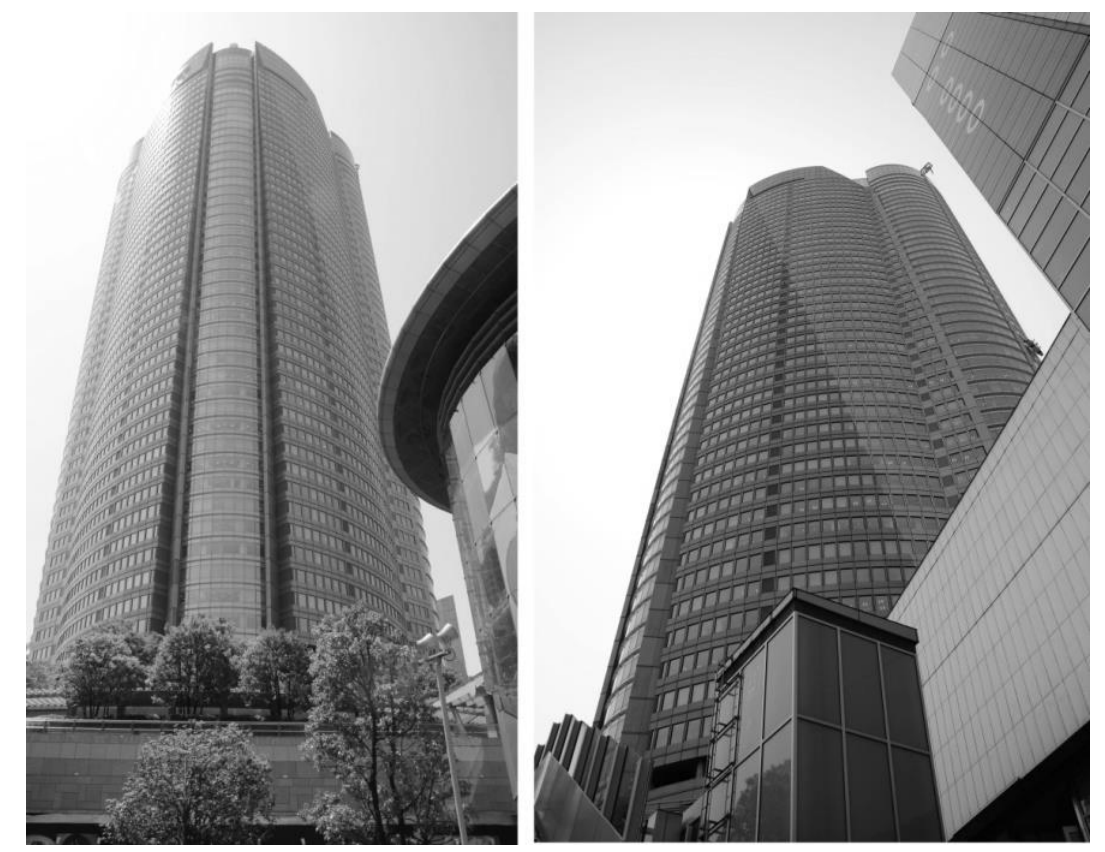

Fig. 17. Roppongi Hills Mori Tower (photographs by authors) 

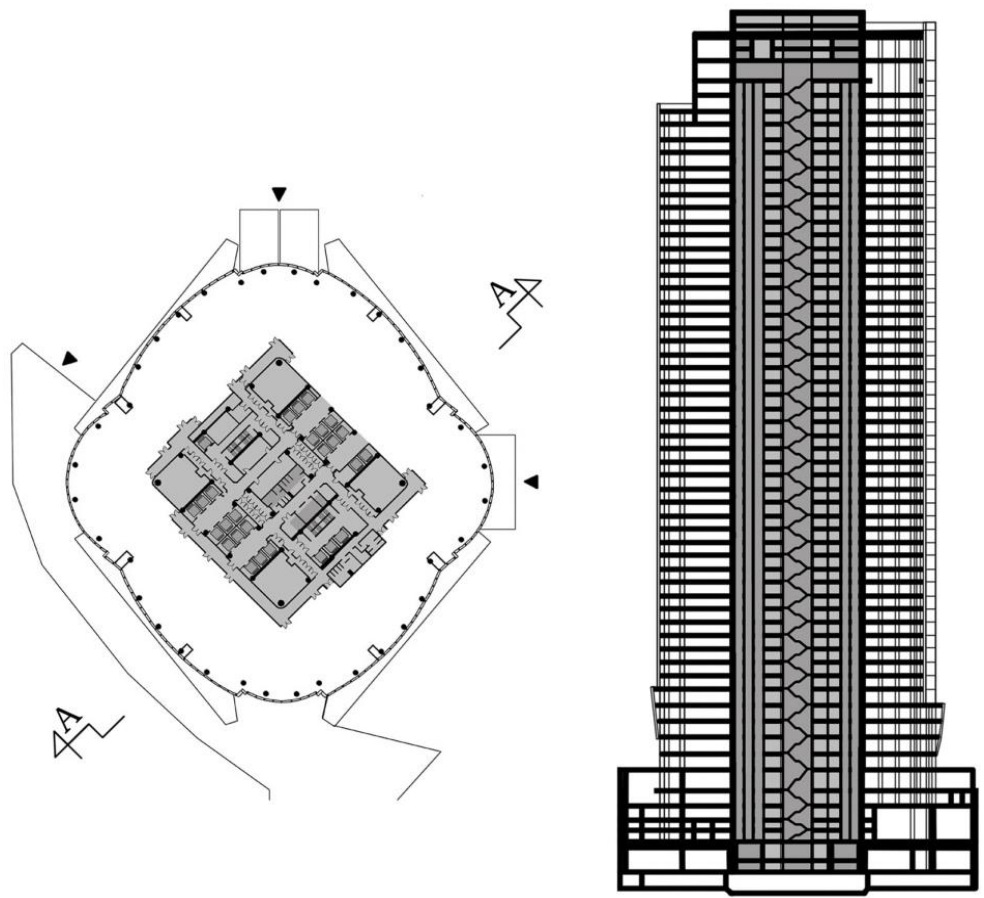

section A-A

Fig. 18. Roppongi Hills Mori Tower: floor plan and section, developed by authors [13]

\subsection{Dentsu Headquaters Building (Tokyo, 2002)}

The Dentsu Headquarters Building is an office high-rise building with a steel structure. The building is $213 \mathrm{~m}$ high and contains 48 floors above-ground level and 5 floors underground (Fig. 19). The skyscraper design was made by the architectural studio Jean Nouvel. This large complex, located in the center of Tokyo, is mainly used as the headquarters of the largest advertising agency in Japan and one of the largest in the world, Dentsu Inc. The skyscraper occupies the area of the old railway line, near the Tokyo station, and is part of the extensive reconstruction of this area. In order to ensure functionality and an original appearance that corresponds to the beginning of the $21^{\text {st }}$ century, three aspects were considered during the design and subsequent implementation of the building: 100 years of operation, symbiosis with the environment and energy saving. In accordance with the urban plan for SIO-SITE (a comprehensive urban development project), the Dentsu building not only provides office space, but also attractive amenities for visitors that integrate commercial and cultural facilities. In the building is located a restaurant, cafe, theater, library, museum and specialist stores. In order to realize the main concept of "100 years of usability", the design aimed for a highly functional, very durable building that would ensure safety from wind and seismic forces.

The building is designed on a triangular plan with an internal atrium and is approximately $120 \mathrm{~m}$ long on its longer side and $41 \mathrm{~m}$ on its shorter side (Fig. 20). The communication part was located along the north façade and in the central part parallel to the obtuse sides of triangle.

The height / width ratio is 5 for the shorter side and 1.7 for the longer side, which classifies this building into that of a slender profile. The interior of the building is a massive 
steel structure with a series of atriums that are characterized by curvature and extensive surfaces [15]. Atriums are located on the north side, while its main façade is oriented from the south. The tower is divided into ten floors, showing the location of various companies. Vertical movement is implemented by panoramic public and office elevators. The elevator battery runs through the entire building, but only reaches the level of the passage. These transition zones determine the main levels of the various atriums. The levels have their own set of elevators for the ten floors occupied by each sector. The façade of the building is fully covered with ceramic printed glass, which not only emphasizes the landscape, but also significantly reduces air-conditioning loads and saves energy. In addition, the light that diffuses and passes through the ceramic printed glass helps daylight to be used with less glare. From the south side, in the façade, ceramic glass with 12 shades from white to gray is used, which creates a very diverse view.

The key element of the design of the structure was to determine the method of deformation control in the transverse direction, where bending is greatest. The main loadbearing structure of the building is a steel mega-frame. These frames are resistant to seismic vibrations and use two types of vibration dampers that are installed in the upper part of the building, controlling lateral and bending deformation (2 Tuned Mass Dampers with Active Mass Damper - total weight equal 440 ton). For the asymmetric configuration of the building, a steel shell filled with concrete with a strength of $80 \mathrm{MPa}$ was used. In the atrium for the frame construction, fire-resistant steel with a maximum thickness of $80 \mathrm{~mm}$ was used. The foundations of the skyscraper were built on granite rock, which was also exposed in the interior of a six-storey space with stone walls and waterfalls.

The Dentsu skyscraper was designed based on the concept of coexistence with the global environment in which energy saving was a priority. In particular, the focus was on using natural energy and increasing energy efficiency resources. The building has at least 35 major architectural and hardware innovations that have effectively contributed to increased energy efficiency and reduced $\mathrm{CO} 2$ emissions. At the time of completion, the building was about $30 \%$ more efficient than conventional constructions of the same scale.
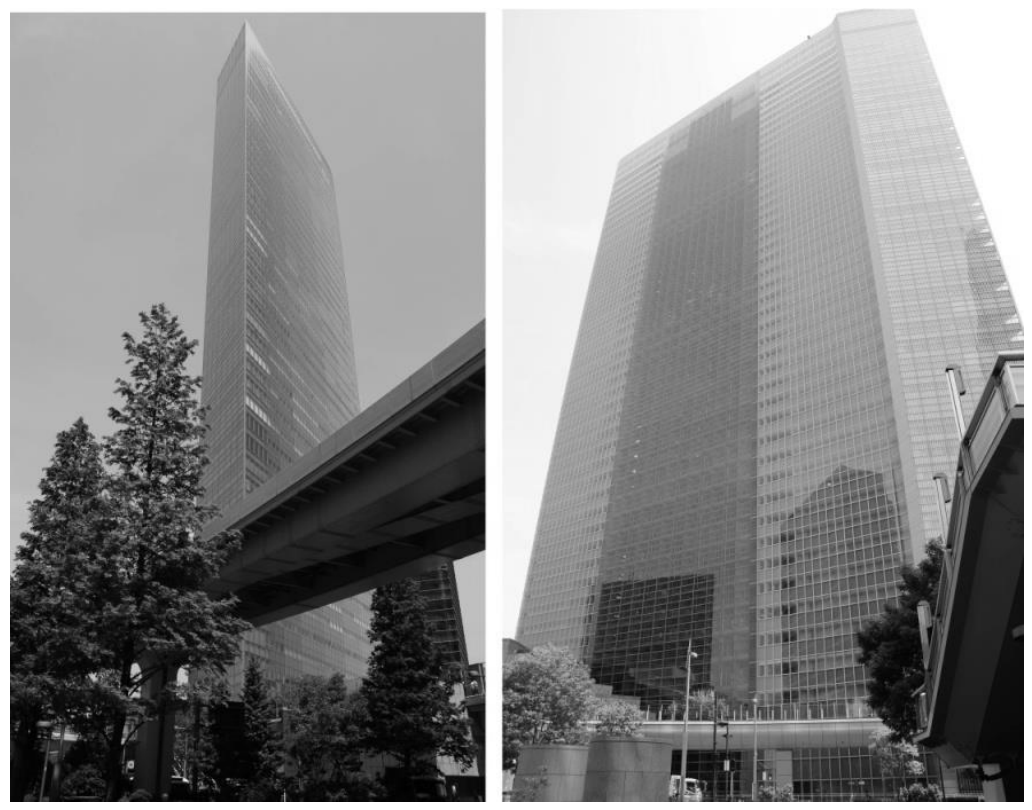

Fig. 19. Dentsu Tower (photographs by authors) 


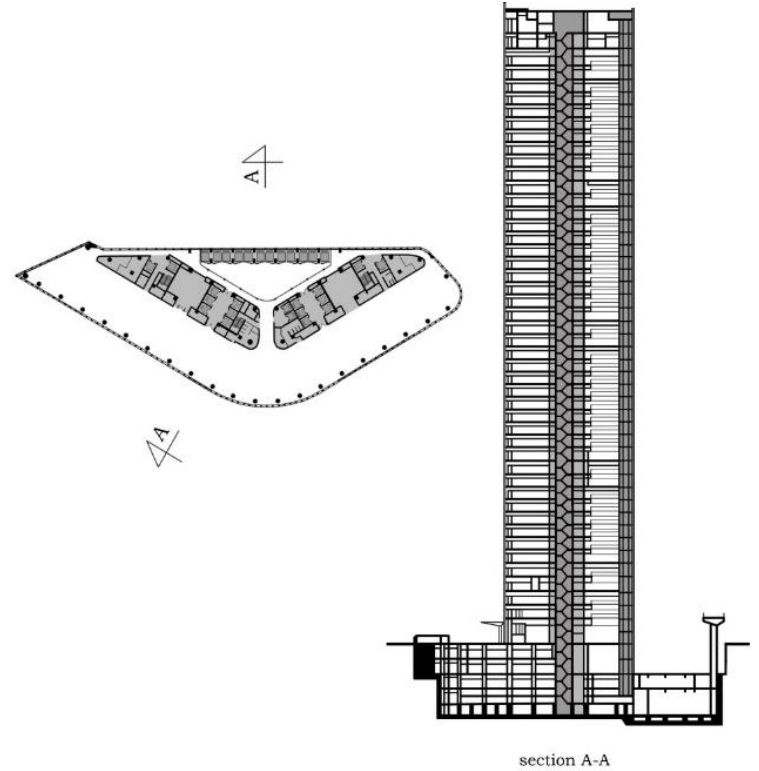

Fig. 20. Dentsu Tower: floor plan and section, developed by authors [15]

\subsection{Mode Gakuen Cocoon Tower (Tokyo, 2008)}

Mode Gakuen Cocoon Tower is an educational high-rise building with a steel and reinforced concrete structure. The building is $203.7 \mathrm{~m}$ high and contains 50 floors aboveground level and four underground floors (Fig. 21). The building design was made by the architectural studio Tange Associates. 50 renowned architectural studios participated in the competition for its design and over 150 proposals were submitted. Mode Gakuen Cocoon Tower is an innovative educational center where three educational institutions are operated: Professional Fashion School (Tokyo Mode Gakuen), Special College of Technology and Design (HAL Tokyo) and Higher Medical School (College Shuto Iko). In terms of the height of the building, it is the world's second tallest educational building after the Moscow State University $(239 \mathrm{~m})$, and holds about 10,000 students. It is located between the most frequented Tokyo train station Shinjuki and the central business district.

The Mode Gakuen Cocoon Tower is designed on a circle plan, with a central communication shaft on a hexagon plan and three extended arms form three axes between which classrooms were arranged on a rectangular plan [16]. These three rectangles are rotated by an angle of 120 degrees in relation to the core (Fig. 22).

Each class has a width of $24 \mathrm{~m}$. The depth of the classrooms varies with height, because the vertical section is an elliptical curve. From the $1^{\text {st }}$ to $50^{\text {th }}$ floor, the class rooms are arranged in a curved form. The internal core in the building consists of staircases and elevator shafts. The spaces between the classrooms are student rooms and are directed in three directions: east, south-west and north-west. Each of these rooms have a three-story atrium with a view of the surrounding landscape. The building has a sectional façade with a dotted print, creating intersecting stripes in various angles. Composite elements were applied to the façade in the form of fluted strips coinciding with the diagrid structure in classrooms.

A lower building with a height of $30 \mathrm{~m}$, which houses two large auditoria and retail outlets, is adjacent to the high-rise building. Both buildings have the same four-story under- 
ground structure, which is used as a car park and retail space. The main entrances were placed from the north and south side in the vestibule connecting the high-rise building with a ballshaped building.

The Mode Gakuen Cocoon Tower has a raft foundation with a thickness of $3.8 \mathrm{~m}$ that cooperates with reinforced concrete piles. The main load-bearing structure of the tower consists of three peripheral elliptical diagrid frames and an internal frame core. The building has relatively high shear deformations in the middle floors due to the bending of each frame. Because the three frames are rigidly connected to the base and the upper part of the construction, the structure can be treated as a portal frame. The perimeter frames have a width of $24 \mathrm{~m}$, with intersections of $4 \mathrm{~m}$ at each floor level, and are curved vertically in the shape of an ellipse. Their task is to transfer transverse forces and overturn moments from the action of wind and seismic effects. In addition, to reduce these impacts on each floor from 15 to 39,6 viscoelastic dampers were used.

The height of each floor is adapted to the elliptical curve, which allows the diagrid elements to cross at the same angle on each floor. The floor beams in the classrooms are the load-bearing element for the storey and connect in a horizontal diagrid frame and the inner core, preventing the buckling of these frames from out of the plane. In the student rooms located in a three-story atrium, the glazing of the façade is three storeys high with a maximum width of $20 \mathrm{~m}$. Vierendele double arched trusses were used to transfer the weight of the façade glass and counteract wind action. Vierendeel trusses are suspended on beams located above, so that no structural element would obstruct the view on any storey. Unlike many other tall buildings in Tokyo, the Gakuen Cocoon Tower does not have a flat roof. This is very important due to the fact that the cleaning system and the provision of space for helicopters is an essential requirement for a high building in Japan. Therefore, in order to fulfill these conditions, a sliding roof was used. A gondola hanger with a cleaning system is installed under a floating roof and moves on "Y" shaped rails with a rotating table in the middle. The hanger is able to provide the gondola to the entire outer surface of the building by extending and turning the arm at each end of the rails. The Mode Gakuen Cocoon Tower has a cogeneration system that generates $40 \%$ of energy, which increases the operational efficiency of the building, as well as reducing energy costs and greenhouse gas emissions. The elliptical shape allows for even distribution of sunlight and the aero-dynamic scattering of strong wind streams.
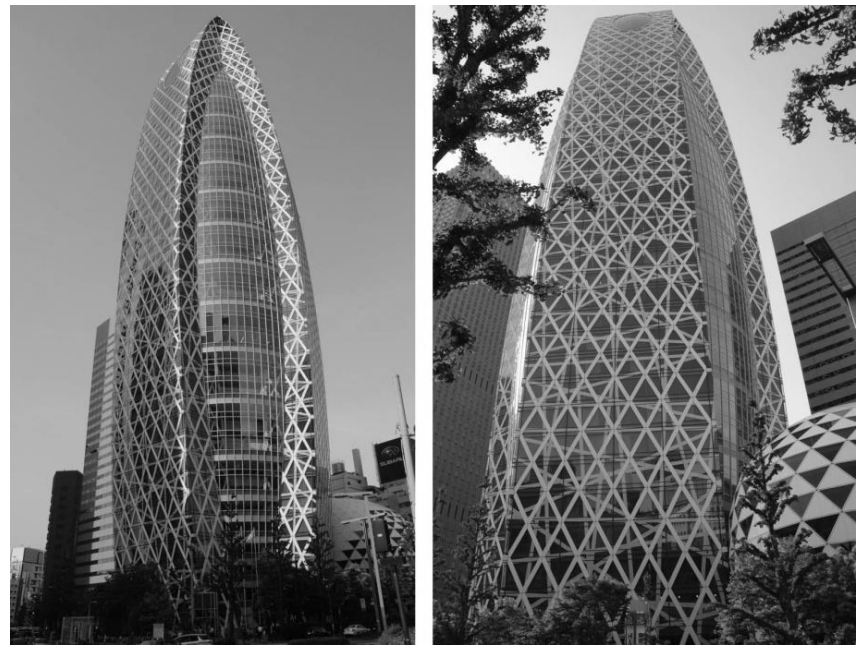

Fig. 21. Mode Gakuen Cocoon Tower (photographs by authors) 


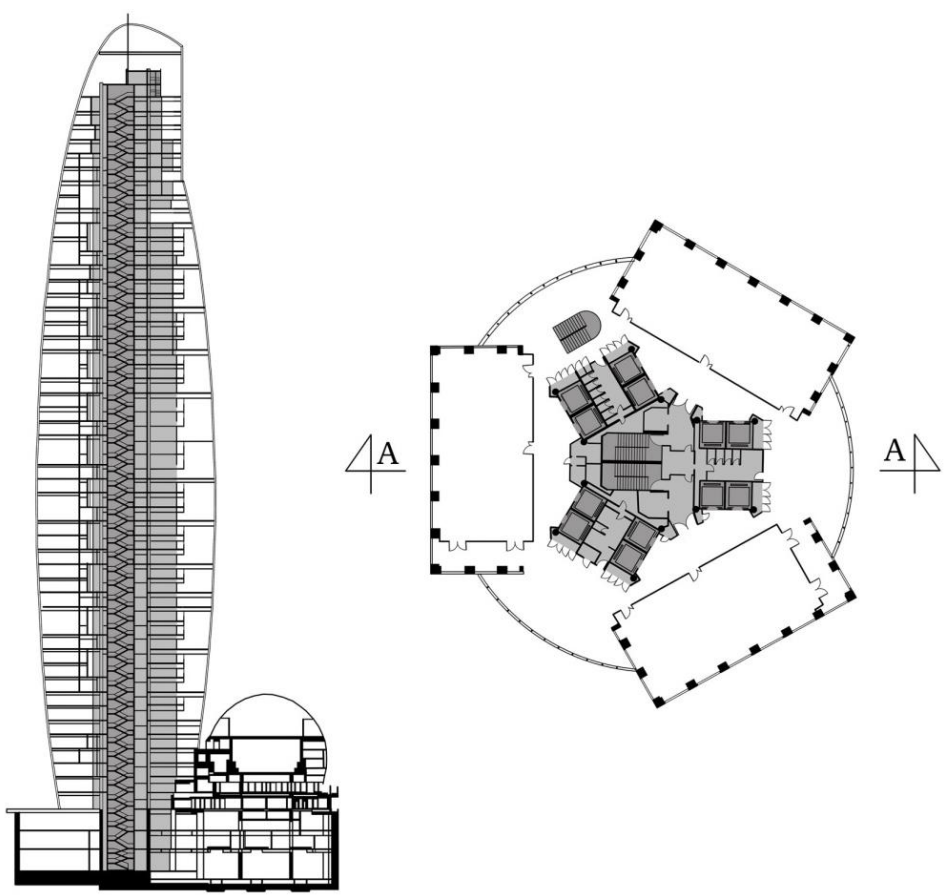

Fig. 22. Mode Gakuen Cocoon Tower: plan and section, developed by authors [16]

\subsection{Mode Gakuen Spiral Towers (Nagoya)}

Mode Gakuen Spiral Towers is educational high-rise building with steel structure. The building is $170 \mathrm{~m}$ and contains 38 floors above and 3 below ground level (Fig. 23). The building was designed by Nikken Sekkei studio. Mode Gakuen Spiral Towers is located on a busy main street of Nagoya City in front of Nagoya Station. The building houses three vocational schools; Mode-Gakuen for fashion, HAL for information technology and design, and ISEN for medicine and welfare. The building is built on an elliptical plan with three niches with a central core in the ellipse form (Fig. 24). The project consists of three spiral wings that are, radially arranged in relation to each other [17]. The entrance to the building is located at ground level. The central element of the facade has horizontal divisions accentuated with balconies and vertical ones with rectangular windows. The outer surface is made of a steel diagrid with triangular windows. The facade is distinguished by triangular windows and horizontal balcony lines.

The planar configuration of each floor changes with the height. 12 straight columns are arranged around the oval core and braces are connected to these columns in a mesh network that forms an inner truss tube. The truss tube is made of concrete-filled steel tubular columns with constructional braces fixed around the base. The columns act as a central pillar supporting the three slightly tapering wings of the building. This tubular structure is very strong and rigid with regard to the horizontal and twisting forces that are generated by earthquakes and high winds. In this type of tower building, there are considerable bending deformations and a high level of axial forces affecting the outer columns, which results in greater deformation in the upper part of the building. The construction of the building in the form of an inner truss tube and two vibration damping systems ensure high resistance to seismic actions. The towers are integrated with mass 
damper systems, expanding columns and active mass dampers. Vibration - damping columns efficiently absorb seismic energy by means of viscosity dampers, which are installed at 26 points on the periphery. There is also a mass damper located on the rooftop. Double-glazed windows and airflow windows are used to reduce heat loads around the perimeter zone. The foundations combine a thick raft slab and cast concrete piles.

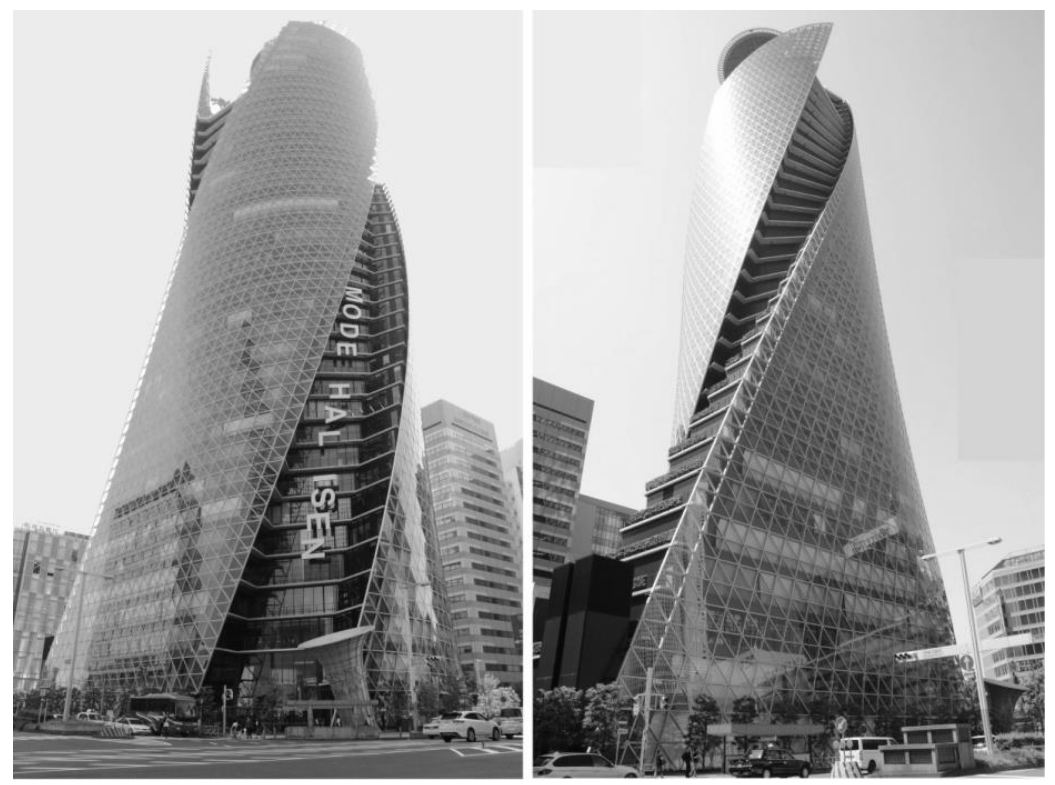

Fig. 23. Mode Gakuen Spiral Towers (photographs by authors)

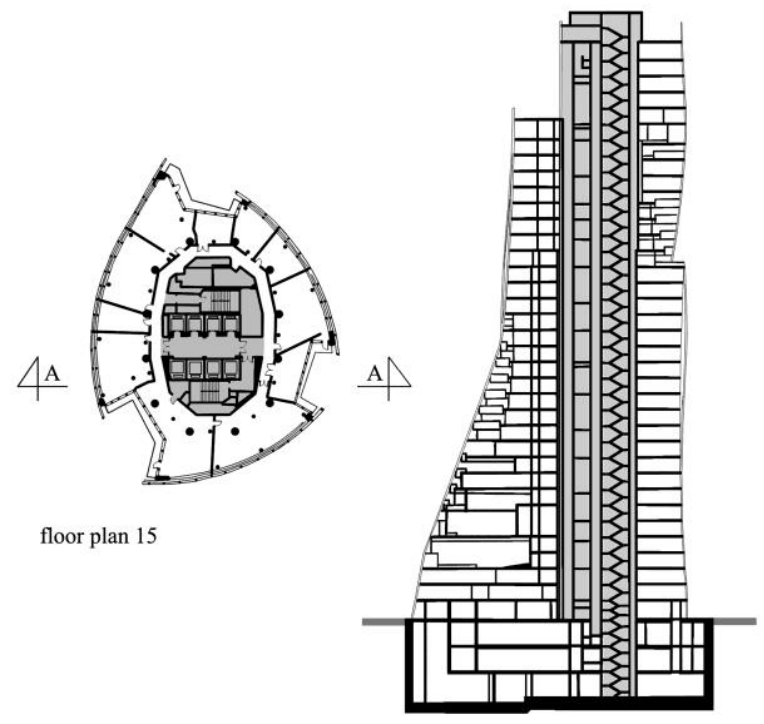

section A - A

Fig. 24. Mode Gakuen Spiral Towers: floor plan and section, developed by authors [17] 


\section{Conclusions}

Due to seismic activity, Japan is a country with very difficult conditions to build, especially high-rise buildings. Historically, traditional construction was characterized by light wooden constructions, usually skeletal and insensitive to slight deformation, with brick buildings being less frequent. Houses consisted of practically one fixed wall, in which there was a recess called takomona, used for storing paintings and works of art. The other walls were made of a lightweight wooden lattice, covered with paper soaked in oil. Characteristic buildings of Japanese architecture were tall and slender pagodas, in which the structure is loaded from above with a massive wooden stake to ensure stability.

Earthquake-proof properties of Japanese timber pagodas have been scientifically studied for a century by researchers to interpret why they have not collapsed during strong earthquakes. The main pile with several roofs and the friction connections between them are working as natural dampers. Damping condition due not only friction at bracket complexes and the other joints but also dissipation energy into ground would be effective in reduction of response to ground motions [18]. Japanese architecture is characterized by asymmetry which is related to commitment to nature. Houses were often built in mountainous areas, on forested slopes. Currently in Japan, we can find many buildings with symmetrical shapes which is related to the influx of Chinese Buddhism and the influence of the Western culture. Traditional residential buildings are being replaced by multi-storey buildings with a higher communication shaft. The contemporary architecture of Japan is also eclecticism, which is characterized by the freedom to mix styles, combining the features of high-tech, deconstructionism, minimalism and metabolism.

Undoubtedly, the least-resistant construction for an earthquake is a skyscraper, which is a certain paradox in comparison with their number in Japan, and especially in Tokyo, which in this respect has the fourth most in the world. Since the Kobe earthquake in 1995, Japan has become a world leader in building new buildings, as well as modernizing old ones so that they can withstand rapid seismic quakes. The high-rise earthquake-proof buildings in Japan are very often constructed using modern "tube" and "tube in tube" systems using the latest high-strength structures, for example, steel columns filled with concrete.

The most modern skyscrapers in Tokyo are able to withstand earthquakes of over seven degrees on the Richter scale. Of course, more forces affect a building with a larger earthquake, and its construction therefore experiences larger displacements. A building's response to earthquakes are vibrations in the form of sinusoidal motion. In order to counteract both these forces and the impact of wind, apart from a rigid construction, very advanced technologies of damping devices are used. For example, the foundations of these buildings (Maison Hermes Tokyo) are mounted with a system of spring or elastomer vibration dampers, due to which tectonic movements affect the upper part of the building to a lesser extent. In addition, as presented by the characteristics of high-rise buildings, viscous oil dampers (Mode Gakuen Cocoon), anti-buckling steel stabilizers (Midtown Tower, Roppongi Hills, Kabukiza Tower) and tuned mass dampers (Tokyo Tree Tower) are used at various levels of these buildings. When using all these supporting elements, it is most important that the location of the center of gravity of the building does not change during earthquakes. The main load-bearing structure of the presented skyscrapers are steel mega-frames with steel columns filled with concrete and an internal frame core. 


\section{References}

[1] www.skyscrapercenter.com/city. [Accessed: 21 Apr 2019].

[2] Perez R. "The Historical Development of the Tokyo Skyline: Timeline and Morphology". Journal of Asian Architecture and Building Engineering, September 2014, pp. 609-615. https://doi.org/10.3130/jaabe.13.609

[3] Malott D., Robertson L., Hiei K., Werner H. „Next Tokyo 2045: A Mile-High Tower Rooted in Intersecting Ecologies”. CTBUH Journal, Issue II, 2015, pp. 30-35.

[4] Tsuji M., Kanno R. "Advances in Steel Structures and Steel Materials in Japan”. Nippon Steel \& Sumitomo Metal Technical Report, no. 113, December 2016, pp. 3-12.

[5] Arch20 - Next Tokyo 2045. Available online: https://www.arch2o.com/next-tokyo-2045kpf/arch2o-next-tokyo-2045-01/ [Accessed: 16 Sept 2019].

[6] Kareem A., Spence J., Bernardini E., Bobby S., Wei D. "Using computational fluid dynamics to optimize tall building design”. CTBUHJ, Issue III, 2013, pp. 38-42.

[7] Kawecki J., Masłowski R. "Zastosowanie tłumików pasywnych quasi-aktywnych i hybrydowych do redukcji drgań sejsmicznych i parasejsmicznych budowli - przegląd rozwiązań” (in Polish). Czasopismo Techniczne, zeszyt 11, 2010, pp. 59-67.

[8] Kareem A., Kijewski T., Tamura Y."Mitigation of Motions of Tall Buildings with Specific Examples of Recent Applications", 1999, p. 104.

[9] Harada T., Yonezu M."Forging a Supertall Compact City". International Journal on Tall Buildings and Urban Habitat, Issue II, 2015, pp. 12-20.

[10] Hanaima A., Hirano T., Tohki H. "Osaka World Trade Center". Structural Engineering International, vol. 8,1998, Issue 1, pp. 28-29.

[11] Mitsui Fudosan Co., Ltd. "Homepage of Tokyo Midtown“, from Tokyo Midtown Website: http://www.tokyo-midtown.com/en/midtown.html. [Accesed: 21 Aug 2018].

[12] Hitomi Y., Takahashi H., Karasaki H. "Toranomon Hills - Super High-Rise Building on Urban Highway". International Journal of High-Rise Buildings, vol. 3, no. 3, 2014, pp. 167-171.

[13] Tsuchihashi T., Yasuda M. "Rapid Diagnosis Systems Using Accelerometers in Sejsmic Damage of Tall Buildings". International Journal of High-Rise Buildings, vol. 6, 2017, pp. 207-216. https://doi.org/10.21022/JJHRB.2017.6.3.207

[14] Alexander L. „The Tokyo skyscrapers that can withstand a major earthquake”. Available online: https://www.ft.com/content/3efc4da8-c3bd-11e2-aa5b-00144feab7de [Accessed: 16 Sept 2019].

[15] Yamanaka M. "Dentsu Building”. Steel Construction Today \&Tomorrow, no 17, 2006.

[16] Noritaka P. “Case Study: Mode Gakuen Cocoon Tower”. CTBUH Research Paper, Issue 1, 2009, pp. 16-19.

[17] Groesbeck C., DeVries J., Klemencic R., McDonald J. "Tall Buildings in Future Development of Metropolitan Universities". CTBUH Research Paper, 9th World Congress, 2012, pp. 707-714.

[18] Toshikazu H., Chikahiro M., Yasushi N., Kazuhito N., Naohito K., Hideyuki M., Masayuki M. "Seismic and Wind Performance of Five-Storied Pagoda of Timber Heritage Structure".

Advanced Materials Research, vols. 133-134, 2010, pp. 79-95.

https://doi.org/10.4028/www.scientific.net/AMR.133-134.79 